\title{
Revenue Estimation of Pit Seam 14 Quarter Mine Block Sequence Design Based on Coal Reference Price Prediction at PT Alam Jaya Pratama, East Kalimantan Province
}

\author{
Rahmat Hidayat ${ }^{\mathrm{a}, *}$, Aryanti Virtanti Anas ${ }^{\mathrm{b}}$, Rizki Amalia ${ }^{\mathrm{c}}$, Muhammad Ramli $^{\mathrm{d}}$, Nirmana Fiqra Qaidahiyani ${ }^{\mathrm{e}}$, \\ Yoga Apri Disetia ${ }^{\mathrm{C}}$ \\ a Department of Mining Engineering, Engineering Faculty, Hasanuddin University. Email: rahmat_26@outlook.com \\ bepartment of Mining Engineering, Engineering Faculty, Hasanuddin University. Email:aryantiv@unhas.ac.id \\ 'Department of Mining Engineering, Engineering Faculty, Hasanuddin University. Email:rizkiamalia@unhas.ac.id \\ ${ }^{\mathrm{d}}$ Department of Mining Engineering, Engineering Faculty, Hasanuddin University. Email:ramli@unhas.ac.id \\ eDepartment of Mining Engineering, Engineering Faculty, Hasanuddin University. Email:nirmana.fiqra.q@unhas.ac.id \\ ${ }^{\mathrm{f}}$ Mine Planning Department, PT Alam Jaya Pratama, East Kalimantan Province.
}

\begin{abstract}
Seam 14 is one of coal prospects owned by PT Alamjaya Bara Pratama (PT ABP) with an estimated coal resources of $\pm 4,022,458.63$ tons which is will be produced in 2020 so that required a pit and mine sequence design used as a guideline in carrying out coal production activities. On the other hand, the uncertainty of coal prices caused the mine sequence design to be evaluated within a certain time as the coal reference price (HBA) was altered and company's production target. The model equation of coal reference price prediction in 2020 was carried out by using multiple linear regression method. Based on that model, prediction of coal reference price was obtained in $\mathrm{CW}$ $1=\$ 80.21$, CW $2=\$ 81.47$ and CW $3=\$ 82.50$. The Pit 14 was designed with the consideration of company's geotechnical recommendation which is can be achieved on the conditions of stripping ratio (SR) of 6 and 7. The mine sequence was designed base on the evaluation of coal production in $2019(\mathrm{CW} 1=\mathrm{SR}>3, \mathrm{CW} 2=3 \leq \mathrm{SR} \leq 6$ and $\mathrm{CW} 3=\mathrm{SR}>6)$. The calculation results of estimated revenue of Pit 14 with SR $=6$ is CW $1=\mathrm{US} \$ 40,131,297.12$; CW $2=\mathrm{US} \$ 36,431,457.31$; and CW $3=\mathrm{US} \$ 19,601,965.40$. Estimated revenue of Pit 14 with SR $=7$ is CW $1=\mathrm{US} \$ 41,821,080.50$; CW $2=\mathrm{US} \$ 39,204,128.39$; and CW $3=\mathrm{US} \$ 31,715,767.60$.
\end{abstract}

Keywords: Coal; coal getting; mine sequence; multiple linear regression; stripping ratio

\section{Introduction}

Seam 14 is one of the coal prospects owned by PT ABP with a large volume of resources which is estimated at $4,022,458.63$ ton and will begin his production in 2020 thus it need a pit design that is used as a guidelines in carrying out that coal production activities [1]. The geometry of a pit design generally influenced by factors such as spatial characteristics of coal deposits, actual topography, geometry of safe slopes, and rates of profit in relation to the used value of stripping ratio (SR) [2].

Natural factors such as geological conditions (spatial deposits and geotechnical characteristics) are factors that occur beyond human control so that when designing the pit must adjust to that condition. On the other hand, the value stripping ratio was influenced by two main factors, namely amount of cost to be incurred to peel top soil and overburden and the coal reference price. The cost of mining operations is a factor that can be controlled by every mining company, but the magnitude of the coal price

*Corresponding author.

Jalan Poros Malino km. 6 Bontomarannu

Gowa, Indonsia 92171 depends on global market conditions. In the last few years, coal price performance in global markets tends to fluctuate as coal demand decreases due to economic retarding in China, other Asian countries and Europe. In addition, increased coal production in South Africa, Colombia and Indonesia caused surplus coal stocks in global markets to increase [3].

Price prediction is an integral part of economic decision making. Specifically, somebody can use predictions to try to earn optimal income from speculative activities, determine optimal government policies, or to make business decisions [4].

Multiple linear regression model is one of the common methods used by academics in making a prediction model. Regression analysis relates to the study of the dependence of a variable called dependent variable on one or more variables (independent variables). Regression analysis aims to estimate and or predict the average value of the dependent variable if the value of the explaining variable is known [5].

The uncertainty of the coal price in the global market and the world economic conditions that have not been stable cause mining companies, especially in Indonesia, 
difficult to choose the coal reference price as an input in designing a pit. On the other hand, coal price is one of the factors that need to be considered in determining the value of breakeven stripping ratio (BESR) as it can lead to the pit design which is made in the beginning of production year should be evaluated same as the mine sequence design also need to be evaluated in line with the change of coal price.

The prediction of coal reference price (HBA) is one of the solutions that can be done to get the approach value of coal reference price (HBA) in the future. Therefore, this research is done to predict the approach value of coal reference price (HBA) which can be used as consideration in determining the magnitude of break even stripping ratio (BESR), create a pit design of seam 14 coal prospects, create a block sequence design based on PT ABP coal production in 2019 and estimate the revenue of each sequence based on the coal reference price prediction.

\section{Research Methods}

Broadly, the research was conducted in three main phases, which is to predict the coal reference price using the econometrics model of multiple linear regression where the predicted result was used in calculating the break even stripping ratio (BESR), create a pit design with consideration of company's geotechnical recommendations, create mine block sequences design based on PT ABP coal production in 2019 and estimate the revenue of each sequence based on the coal reference price prediction.

\subsection{Data collection}

The coal reference price (HBA) prediction is done by using multiple linear regression models, the pit design and mine block sequences of coal mining requires some data to get the research activities can be done properly.

\subsubsection{Coal reference price prediction data}

Type of data that was used in predicting the coal reference price (HBA) by using the multiple linear regression is time series data, namely:

1. Coal Reference Price

The coal reference price was issued monthly by the Ministry of Energy and Mineral Resources of the Republic of Indonesia. Coal reference price data in the time span of January 2009 until March 2019 was used in this research.

2. WTI Crude Oil Price

The WTI crude oil price was derived from www.investing.com which provides information about the movement and magnitude of WTI coal price periodically. WTI crude oil price data in the time span of January 2009 until March 2019 was used in this research.

3. Coal Consumption for Electricity Generation

The coal consumption was obtained from the monthly report issued by the U.S. Energy Information Administration. Coal consumption data in the time span of January 2009 until March 2019 was used in this research.
4. Renewable Energy Consumption

The renewable energy consumption was obtained from the monthly report issued by the U.S. Energy Information Administration. Renewable energy consumption data in the time span of January 2009 until March 2019 was used in this research.

5. Natural Gas Price

The natural gas price was derived from www.investing.com which provides information about the movement and magnitude of natural gas price periodically. Natural gas price data in the time span of January 2009 until March 2019 was used in this research.

6. Exchange Rate of Rupiah Against US Dollar The exchange rate was updated periodically by the Ministry of Trade of the Republic of Indonesia. Exchange rate data in the time span of January 2009 until March 2019 was used in this research.

7. Oil and Gas Commodity Price Projection for 2020 2025

Oil and gas commodity price projection data was obtained from www.pubdocs.worldbank.com which is that website belongs to World Bank Institution.

\subsubsection{Pit and mine block sequence design data}

The required data in designing of pit and mine block sequence, namely:

1. Geological Drilling

The geological drilling data was used in geological modelling of coal deposits (gridded seam model). Geological drilling data was obtained from the Geological Division of PT ABP.

2. Actual Topography Survey

The actual topography survey is a data that indicating the changes of the topographical condition along with the mine progress in certain periods. Actual topography survey data was obtained from the Civil Engineering Division of PT ABP.

3. Bench Geometry Recommendation

The bench geometry recommendation was issued by the Geotechnical Division of PT ABP based on geotechnical studies that was conducted in seam 14 coal prospects area. The recommended geometry is:

a. Single slope angle (high wall) $: 60^{\circ}$

b. Bench width (high wall) $: 5$ meter

c. Bench height (high wall) : 10 meter

d. Maximum request level (RL) : 50 meter

e. Overall slope angle (low wall) : $20^{\circ}$ (based on seam 14 dip which is plan to be the pit floor)

f. Ramp width : Based on Komatsu HD-785 dimension.

4. Mining Equipment Specification

The largest mining equipment that will be used in seam 14 coal prospects area was the Komatsu HD-785 with the detail specification is written in the Komatsu Specification Handbook of HD-785.

5. Mining Operational Costs

The mining operational costs was obtained from the Directorate General of Mineral and Coal of the Republic of Indonesia which was contained in the Kepdirjen Minerba No. 579.K/32/DJB/2015. Mining operational costs can be seen in Table 1. 
Table 1. Mining operational costs

\begin{tabular}{|c|c|c|c|c|}
\hline Costs Type & Description & Units & Costs Amount & Planned Costs \\
\hline \multirow{4}{*}{$\begin{array}{l}\text { Direct Production } \\
\text { Costs }\end{array}$} & Overburden Removal & $\mathrm{US} \$ / \mathrm{bcm}$ & 2.41 & 2.41 \\
\hline & Overburden Hauling & US\$/ton/km & 1.74 & 3.48 \\
\hline & Coal Getting & US\$/ton & 1.70 & 1.70 \\
\hline & $\begin{array}{l}\text { Coal Transportation to the coal } \\
\text { processing plant location }\end{array}$ & $\mathrm{US} \$ / \mathrm{ton} / \mathrm{km}$ & 0.28 & 2.52 \\
\hline \multirow{2}{*}{$\begin{array}{l}\text { Indirect Production } \\
\text { Costs }\end{array}$} & Coal Processing & US\$/ton & 1.98 & 1.98 \\
\hline & $\begin{array}{l}\text { Amortization, land acquisition or } \\
\text { land replacement and depreciation }\end{array}$ & US\$/ton & 6.88 & 6.88 \\
\hline \multirow{7}{*}{$\begin{array}{c}\text { General and } \\
\text { Administration Costs }\end{array}$} & $\begin{array}{l}\text { A. Utilization, management of } \\
\text { reclamation and post-mining } \\
\text { environments }\end{array}$ & US\$/ton & 0.55 & 0.55 \\
\hline & B. Occupational Health and Safety & & & \\
\hline & C. Community Development & & & \\
\hline & Overhead & US\$/ton & 2.07 & 2.07 \\
\hline & Fixed Dues & US\$/ton & 0.11 & 0.11 \\
\hline & Royalty & US\$/ton & $20.3 \%$ & 4.41 \\
\hline & Margin & US\$/ton & $25 \%$ & 6.53 \\
\hline
\end{tabular}

\subsection{Data processing and analysis}

Data processing and analysis was conducted in the Mine Planning and Valuation Laboratory, Mining Engineering Department, Hasanuddin University. The data processing and analysis is done by using the Eviews 9 in creating the econometrics model of multiple linear regression to predict the coal reference price (HBA), MineScape 5.7 is use in designing the pit and block sequence, and Microsoft Excel 2010 is use in further output data processing from Eviews 9 and MineScape 5.7. The research stages are:

1. Creating an Econometric Model of Coal Reference Price Prediction

Prediction of the coal reference price was carried out by using econometrics model of multiple linear regression. Coal reference price prediction equation was obtained from Eviews 9.

2. Econometric Model Validation of Coal Reference Price Prediction

The validation of econometric model was carried out by using the Mean Absolute Percentage Error (MAPE) test.

3. Pit Limit Design

The pit limit was designed base on company's geotechnical recommendation. MineScape 5.7 was used in designing the pit limit.

4. Pit Design

Pit design was created based on geotechnical recommendation and ramp width calculation in straight and corner condition. MineScape 5.7 was used in designing the pit.

5. Calculation of Mineable Reserve

The number of mineable reserve was obtained from the intersection of pit design and actual topography. The calculation was performed by using Microsoft Excel 2010.

6. Quarter Mine Block Sequence Design

The quarter mine block sequence design was created base on evaluation of PT ABP coal production in 2019. Block sequence design was carried out by using MineScape 5.7.
7. Revenue Estimation of Quarter Mine Block Sequence Revenue estimation was calculated by multiplying the coal getting of pit design with coal reference price prediction using Microsoft Excel 2010.

\section{Research Results}

\subsection{Multiple linear regression model and coal reference price prediction}

Econometric model of multiple linear regression was obtained by interpreting the estimated outcome of the equation model generated by Eviews 9 (Table 2). The multiple linear regression equation model was used to perform the coal reference price prediction.

Before interpreting the equation of coal reference price prediction, previously the multiple linear regression need to be tested by the classic assumption test which is consists of normality test, heteroscedasticity test, multicollinearity test, autocolleration test, t-test, F-test, and coefficient determination test.

\subsubsection{Normality test}

Based on histogram of the models that shows a form like a bell and the value of Probability Jarque-Bera $>0.05$ ( $\alpha$ ) (Fig. 1) it can be concluded that the model was distributed normally.

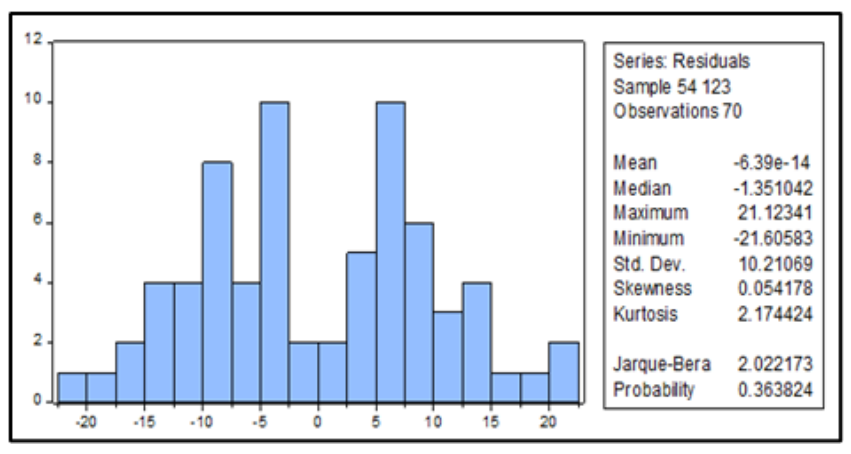

Figure 1. Histogram of econometric model 
Table 2. Multiple linear regression model results

\begin{tabular}{lcccc}
\hline \multicolumn{1}{c}{ Variable } & Coefficient & Std. Error & t-Statistic & Prob. \\
\hline C & -164.5968 & 33.15924 & -4.96383 & 0 \\
NG & 4.896968 & 2.915754 & 1.67949 & 0.0979 \\
ERC & 0.089055 & 0.019398 & 4.59107 & 0 \\
\hline ER & 0.008979 & 0.001875 & 4.78846 & 0 \\
COP & 0.498939 & 0.108657 & 4.59187 & 0 \\
CC & $-1.45 \mathrm{E}-05$ & 0.000153 & -0.09477 & 0.9248 \\
\hline$R$-squared & 0.601396 & Mean dependent var & & 76.9076 \\
Adjusted $R$-squared & 0.570255 & S.D. dependent var & & 16.1728 \\
S.E. of regression & 10.60204 & Akaike info criterion & & 7.64179 \\
Sum squared resid & 7193.814 & Schwarz criterion & & 7.83452 \\
Log likelihood & -261.4625 & Hannan-Quinn criter. & & 7.71834 \\
$F$-statistic & 19.31208 & Durbin-Watson stat & & 0.45434 \\
Prob(F-statistic) & 0 & & \\
\hline
\end{tabular}

Table 3. Glejser heteroskedasticity test result

\begin{tabular}{|c|c|c|c|}
\hline \multicolumn{4}{|c|}{ Heteroskedasticity Test: Glejser } \\
\hline$F$-statistic & 0.526809 & Prob. F(5,64) & 0.7551 \\
\hline Obs*R-squared & 2.767102 & $\begin{array}{l}\text { Prob.Chi- } \\
\text { Square(5) }\end{array}$ & 0.7358 \\
\hline Scaled explained SS & 1.719221 & $\begin{array}{l}\text { Prob Chi- } \\
\text { Square(5) }\end{array}$ & 0.8865 \\
\hline
\end{tabular}

Table 4. VIF test result

\begin{tabular}{lccc}
\hline Variable & $\begin{array}{c}\text { Coefficient } \\
\text { Variance }\end{array}$ & $\begin{array}{c}\text { Uncentered } \\
\text { VIF }\end{array}$ & $\begin{array}{c}\text { Centered } \\
\text { VIF }\end{array}$ \\
\hline $\mathrm{C}$ & 1099.535 & 684.7437 & NA \\
NG & 8.501624 & 55.27376 & 2.591778 \\
ERC & 0.000376 & 178.5108 & 1.592015 \\
ER & $3.52 \mathrm{E}-06$ & 377.9009 & 2.499943 \\
COP & 0.011806 & 33.58642 & 3.373953 \\
CC & $2.35 \mathrm{E}-08$ & 55.08977 & 2.007341 \\
\hline
\end{tabular}

\subsubsection{Heteroskedasticity test}

Heteroskedasticity test was carried out by using Glejser Test (Table 3), it shows that the value of Probability F-Statistic is 0.7551 which is greater than 0.05 $(\alpha)$ thus it can be concluded that the model has no heteroscedasticity symptoms.

\subsubsection{Multicollinearity test}

Generally, the statisctic tool that was used to find out the multicollinearity symptomps in econometric model is variance inflation factor (VIF). Based on Table 4, it shows that the value of Centered VIF from all of the variable in model was lower than 10 so it can be concluded that there is no multicollinearity symptomps.

\subsubsection{Autocolleration test}

Autocolleration test can be done by using the DurbinWatson Test, the criteria that used in making the decision from Durbin-Watson Test is:
1) $\mathrm{D}-\mathrm{W}<-2$
: Positive Autocolleration
2) $\mathrm{D}-\mathrm{W}>+2$ : Negative Autocolleration
3) $2<\mathrm{D}-\mathrm{W}<+2$ : No Autocolleration

Based on Table 2, it shows that the value of Durbin Watson Statistic is 0.45434 so it can be concluded that there is no autocolleration symptomps because the value of D-W Statistic had been meet the third criteria of Durbin Watson Test.

\subsubsection{F test}

The aim of $\mathrm{F}$ test is to find out the influence proportion of independent variable which is used in constructing econometric model simultaneously to the dependent variable. Based on Table 2, it shows that the value of Probability F-Statistic is 0 which is lower than $0.05(\alpha)$ thus it can be concluded that all the independent variable in equation model simultaneously influenced the dependent variable.

\subsection{6. $t$ test}

The aim of $\mathrm{F}$ test is to find out the influence proportion of independent variable which is used in constructing econometric model partially to the dependent variable. Based on Table 2, it shows that almost all of the independent variable has value of t-Statistic lower than $0.05(\alpha)$ which is influenced the value of dependent variable partially except for natural gas and coal consumption. 


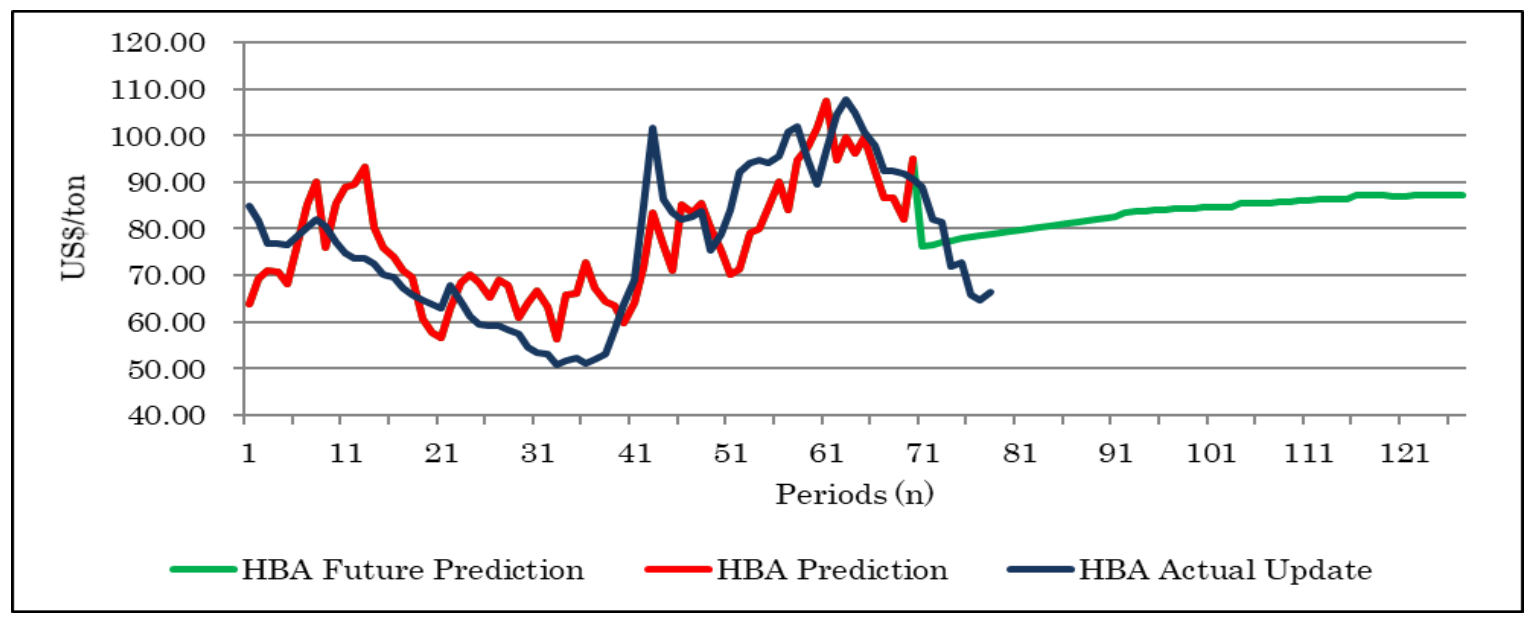

Figure 2. Comparative graphic of HBA actual and prediction

\subsubsection{Coefficient determination test}

The aim of coefficent determination test is to find out the influenced proportion of independent variable to dependent variable in percentage. Based on Table 2, it shows that the value of Adjusted R Square is 0.570255 so it can be concluded that the influenced proportion of independent variable is $57 \%$.

\subsubsection{Model validation and interpretation}

Before interpreting the model equation of coal reference price prediction, previously the model must be validated using Mean Absolute Percentage Error (MAPE). Based on the validation result, the value of MAPE is $12.04 \%$ it means that the model has a good performance to use in predicting coal reference price. Deviation between predicted and actual value can be seen in Figure 2 . Now, the model equation can be interpreted from Table 2 and the equation result is:

$$
\begin{aligned}
H B A= & -164,5968+[4,896968(N G)] \\
& +[0,089055(E R C)]+[0,008979(E R)] \\
& +[0,498939(C O P)]-[0,0000145(C C)]
\end{aligned}
$$

where

NG : Natural gas price

ERC : Renewable energy consumption

ER : Exchange rate of rupiah against dollar

COP : WTI crude oil price

CC : Coal consumption for electricity generation

Before predicting the coal reference price using the chosen model equation, previously the value of independent variable for prediction observations need to be known by using Simple Moving Average (SMA) Method for independent variable that had tendency to increased or decreased in certain period and for the value of independent variable that had tendency to fluctuate in certain period such as Natural Gas and WTI Crude Oil Price were determined from Oil and Gas Price Projection 2020 - 2025 by World Bank Institution. Prediction result of coal reference price can be seen in Table 5 .
Table 5. Coal reference price prediction results (2020)

\begin{tabular}{cc}
\hline Periode & HBA $($ Forecast $)$ \\
\hline Januari - 20 & 79.43 \\
Februari - 20 & 79.71 \\
Maret - 20 & 79.96 \\
April-20 & 80.21 \\
Mei - 20 & 80.42 \\
Juni - 20 & 80.72 \\
Juli - 20 & 81.09 \\
Agustus - 20 & 81.47 \\
September-20 & 81.79 \\
Oktober - 20 & 82.06 \\
November-20 & 82.28 \\
Desember - 20 & 82.50 \\
\hline
\end{tabular}

\subsection{Pit and quarter mine block sequence design}

\subsubsection{Estimated mining operational costs}

Mining operational costs is one of the important factors that need to be considered in determining the value of break even stripping ratio based on coal reference price prediction (HBA). As can be seen in Table 1, the amount cost of overburden stripping is $\$ 2.41 / \mathrm{bcm}$ and total mining operation cost (exclude overburden stripping cost) is $\$ 30.22 /$ ton.

\subsubsection{Calculation of break even stripping ratio (BESR(2))}

The minimum and maximum value of coal reference price prediction (HBA) were used in this research to find out the allowable value of stripping ratio (SR) in creating pit design. Based on coal price prediction (HBA) as a whole, the minimum value is $\$ 76,57 /$ ton in Mei 2019 and the maximum value $\$ 87,31 /$ ton in January 2023 .

1. Value of BESR(2) if HBA Prediction is $\$ 76,57 /$ ton

Balance $=$ HBA Prediction-Operational Mine Costs

Balance $=\$ 76,57 /$ ton $-\$ 30,22 /$ ton

Balance $=\$ 46,35 /$ ton

Furthermore, the calculation value of BESR (2) can be done by using the following equation: 
$\llbracket$ BESR \_ $((2))=$ Balance $/($ Overburden Stripping Cost $)$

bcm/ton

2. Value of BESR(2) if HBA Prediction is $\$ 87,31 /$ ton Balance $=$ HBA Prediction $-\sum$ Operational Mine Costs Balance $=\$ 87,31 /$ ton $-\$ 30,22 /$ ton

Balance $=\$ 57,09 /$ ton

Furthermore, the calculation value of $\operatorname{BESR}(2)$ can be done by using the following equation:

$\llbracket$ BESR】_ $((2))=$ Balance/(Overburden Stripping Cost)

【BESR】_ $((2))=(\$ 57,09 /$ ton $) /(\$ 2,41 / \mathrm{bcm})=23,69 \approx 24$ $\mathrm{bcm} / \mathrm{ton}$

\subsubsection{Pit limit design}

Technical factors that affect the determining and designing of pit limit design is stripping ratio which is calculated with an approach to $\operatorname{BESR}(2)$, recommended bench geometry based on geotechnical study, actual topography and geological conditions. The pit limit design was done by using MineScape 5.7 and the result can be seen in Figs. 3 and 4.

\subsubsection{Pit and disposal design}

The calculation of mine haul road (ramp) geometry must be done before creating the pit design. Generally, the mine haul road geometry was calculated in two different conditions namely straight and corner condition. The mine haul road geometry must be adjusted to the largest equiopment that will operate in the pit location (Komatsu HD 785).

1. Ramp width (straight condition)

The maximum width (Wt) of Komatsu HD 785 is 6.885 meters, thus the ramp width was calculated on a straight condition with two lanes (n) as follows.

L_min $=n$.W_t+(n+1) $(0,5$. W_t $)$

L_min $=2.6,885 \mathrm{~m}+(2+1)(0,5.6,885 \mathrm{~m})$

$\mathrm{L} \min =24,0975 \mathrm{~m} \approx 24,1 \mathrm{~m}$

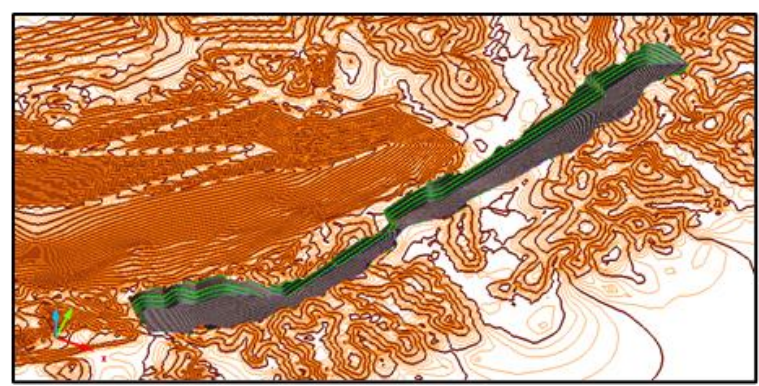

Figure 3. Pit Limit Design $(S R=6)$

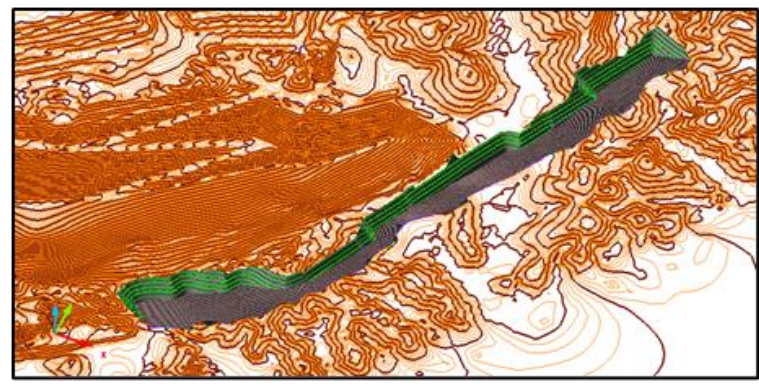

Figure 4. Pit Limit Design $(\mathrm{SR}=7)$
2. Ramp width (turn condition)

Komatsu HD 785 has a trail width (U) at 1.716 meters, front tire width when making a turn $(\mathrm{Fa})$ at 1.410 and rear tire width when making a turn $(\mathrm{Fb})$ at 2.093 meters, and the width of roadside $(\mathrm{Z})$ at 4.679 meters. $\mathrm{W} \_\min =2\left(\mathrm{U}+\mathrm{F} \_\mathrm{a}+\mathrm{F} \_\mathrm{b}+\mathrm{Z}\right)+\mathrm{C}$

W_min $=2(1,716 \quad \mathrm{~m}+1,410 \quad \mathrm{~m}+2,093 \quad \mathrm{~m}+4,679$ m) $+4,679 \mathrm{~m}$

W_min $=24,475 \mathrm{~m} \approx 24,5 \mathrm{~m}$

The disposal design that created in this research was designed by continuing the existed disposal area of Pit 7 (Eastern Disposal). This is done based on some technical consideration, such as to minimize the amount of run off water that flows direct to the pit. The pit design can be seen in Figs. 5 and 6.

\subsubsection{Mineable coal reserve estimation}

Determining the loss factor in estimating the mineable coal reserve is important because the result will become more realistic to the actual operational condition. The value of loss factor is 0.2 , it means that $10 \mathrm{~cm}$ on roof and floor side of the coal seam wouldn't be included in estimation process. The minimum thickness of coal seam that will be included in estimating the coal reserve is 30 $\mathrm{cm}$. The results of mineable coal reserve estimation can be seen in Table 6.

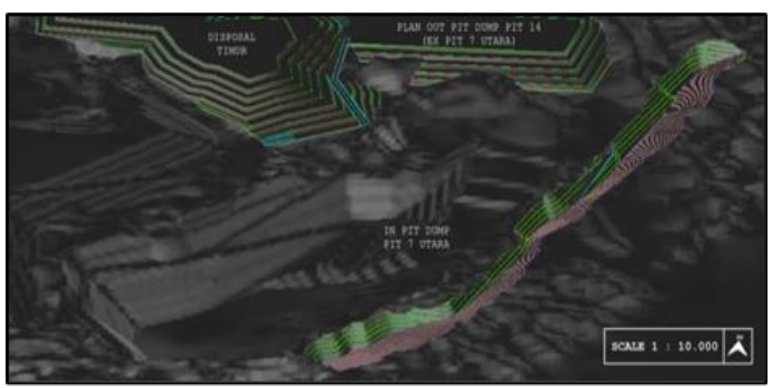

Figure 5. Pit 14 Design $(S R=6)$

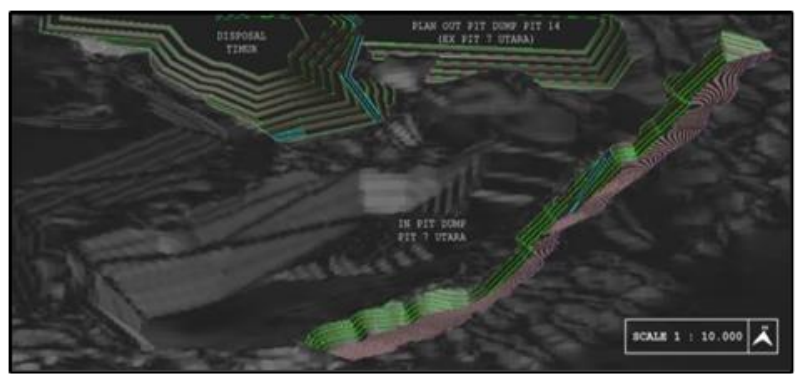

Figure 6. Pit 14 Design $(S R=7)$

Table 6. Mineable coal reserve estimation results

\begin{tabular}{ccc}
\hline Pit 14 & $\begin{array}{c}\text { OB Removal } \\
(\mathbf{b c m})\end{array}$ & $\begin{array}{c}\text { Coal Getting } \\
\text { (ton) }\end{array}$ \\
\hline SR 6 & $7,312,524.70$ & $1,190,194.65$ \\
SR 7 & $9,602,251.09$ & $1,391,812.52$ \\
\hline
\end{tabular}




\subsubsection{Quarter mine block sequence design}

The scenario of quarterly mine block sequence design was determined base on PT ABP coal production in 2019. Pit 7 North is one of the pit owned by PT ABP wiould be mined out at the end of the third quarter of 2019 with stripping ratio $(\mathrm{SR}=3)$ and because of that $\mathrm{PT} \mathrm{ABP}$ will be facing production deficit in the beginning of quarter 1 in 2020. Thus, Pit 14 was designed to avoid the production deficit and the mine block sequence scenario (Figures 7 and 8 ) that will be use is

1) Quarter $1=\mathrm{SR}<3$ (Blue Zone)

2) Quarter $2=3 \leq \mathrm{SR} \leq 6$ (Green Zone)

3) Quarter $3=\mathrm{SR}>6$ (Red Zone)

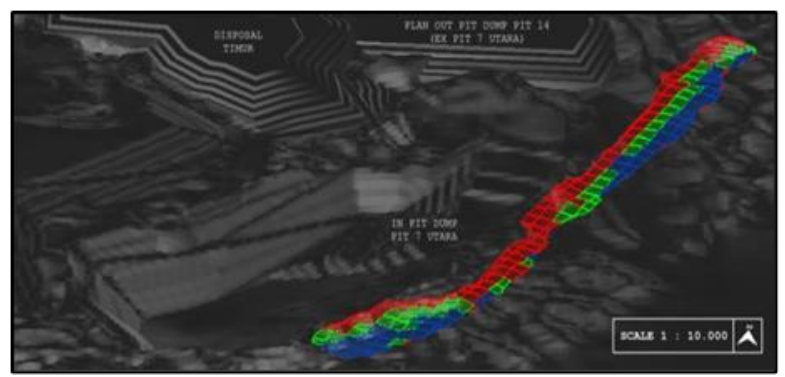

The estimated revenue of Pit $14(\mathrm{SR}=6)$ and $(\mathrm{SR}=7)$ block sequence as can be seen in Table 7 and 8 shows that there is a downtrend but on the other side the coal reference price prediction was increased until the end of quarter 3. It's happen because there is no synchronization between the amount of coal getting and the movement of coal reference price prediction which is cannot be controlled by using the mine block sequence method. The comparative histogram of Pit 14 estimated revenue can be seen in Figure 9.

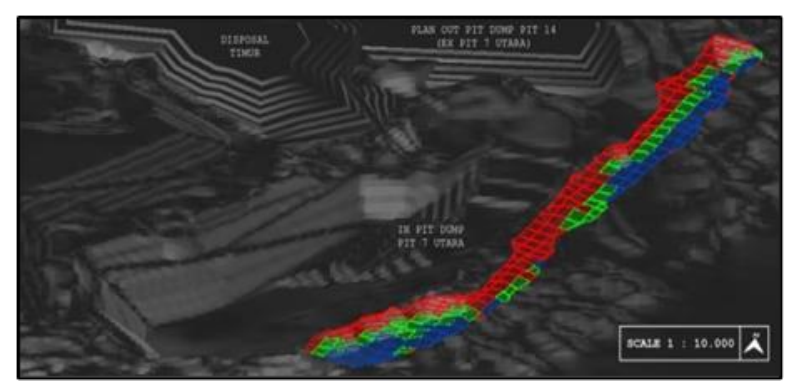

Figure 8. Pit $14(\mathrm{SR}=7)$ mine block sequence

Figure 7. Pit $14(\mathrm{SR}=6)$ mine block sequence

Table 7. Revenue estimation results of pit $14(\mathrm{SR}=6)$ for 2020 production

\begin{tabular}{|c|c|c|c|c|c|c|}
\hline Periods & $\begin{array}{l}\text { Sequence } \\
\text { Scenario }\end{array}$ & $\begin{array}{l}\text { OB Removal } \\
\text { (bcm) }\end{array}$ & $\begin{array}{l}\text { Coal Getting } \\
\text { (ton) }\end{array}$ & $\begin{array}{l}\text { HBA } \\
\text { (\$/ton) }\end{array}$ & $\begin{array}{c}\text { Estimated } \\
\text { Revenue (\$) }\end{array}$ & SR \\
\hline CW 1 & $\mathrm{SR}<3$ & $1,268,103$ & 500,328 & 80.21 & $40,131,297$ & 3 \\
\hline $\mathrm{CW} 2$ & $3 \leq \mathrm{SR} \leq 6$ & $2,491,213$ & 447,176 & 81.47 & $36,431,457$ & 6 \\
\hline CW 3 & $S R>6$ & $3,541,863$ & 237,600 & 82.50 & $19,601,965$ & 15 \\
\hline \multicolumn{2}{|c|}{ Grand Total } & $7,301,180$ & $1,185,104$ & - & $96,164,720$ & - \\
\hline \multicolumn{2}{|c|}{ Stripping Ratio } & \multicolumn{5}{|c|}{6} \\
\hline
\end{tabular}

Tabel 8. Revenue estimation results of pit $14(\mathrm{SR}=7)$ for 2020 production

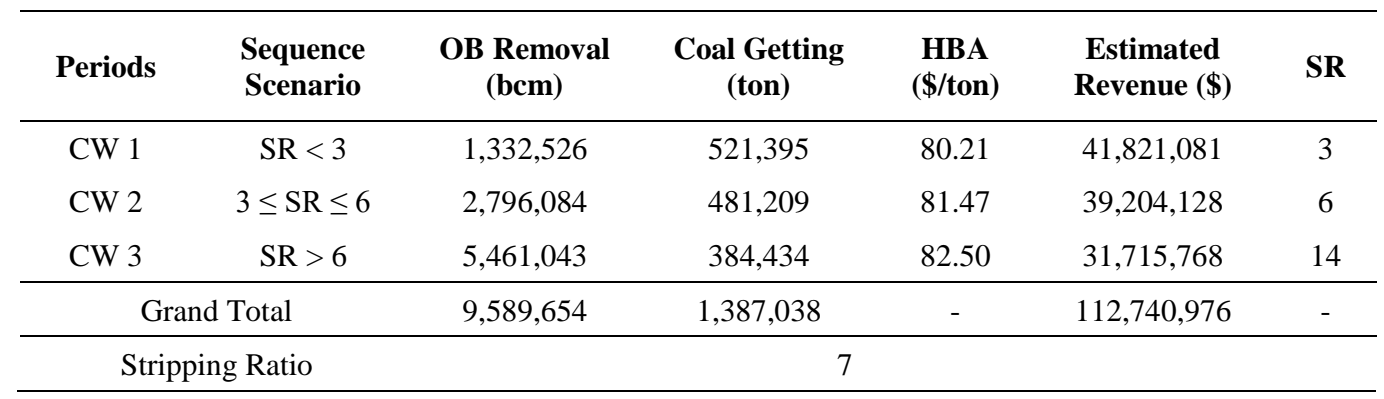

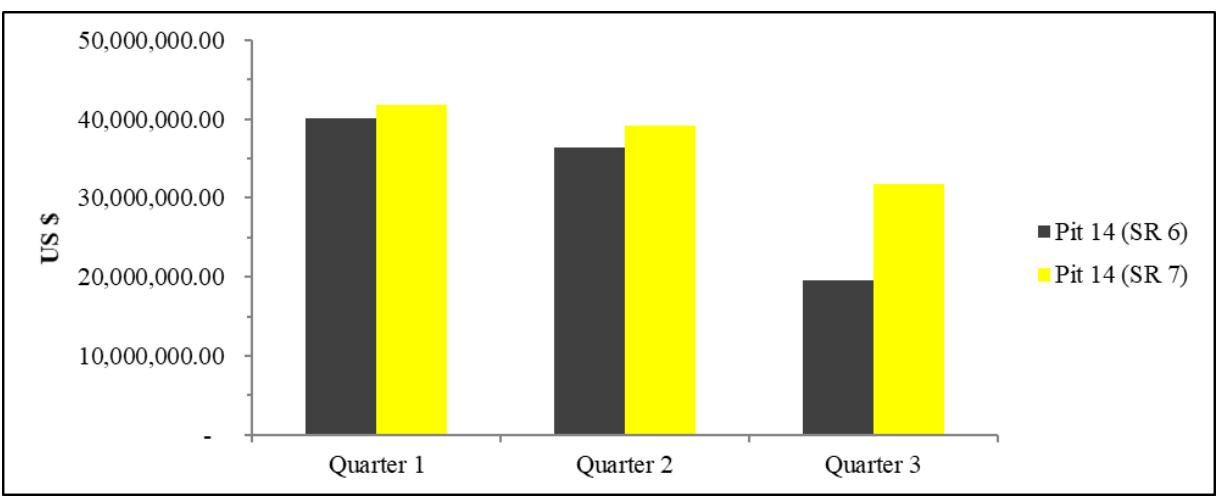

Figure 9. Estimated revenue comparison between Pit 14 SR 6 and SR 7 
Table 9. Profit calculation results of pit 14 block sequence scenario

\begin{tabular}{|c|c|c|c|c|c|c|c|}
\hline \multirow[b]{2}{*}{ SR } & \multicolumn{2}{|c|}{ Description } & \multicolumn{2}{|c|}{ Production Cost } & \multirow{2}{*}{$\begin{array}{c}\text { Estimated } \\
\text { Prod. } \\
\text { Cost }(\$)\end{array}$} & \multirow{2}{*}{$\begin{array}{c}\text { Estimated } \\
\text { Revenue (\$) }\end{array}$} & \multirow[b]{2}{*}{ Profit (\$) } \\
\hline & OB (bcm) & Coal (ton) & $\begin{array}{c}\text { OB } \\
(\$ / b c m)\end{array}$ & Coal $(\$ /$ ton $)$ & & & \\
\hline 6 & $7,301,180$ & $1,185,104$ & 5.89 & 26.74 & $74,695,254$ & $96,164,720$ & $21,469,466$ \\
\hline 7 & $9,589,654$ & $1,387,038$ & 5.89 & 26.74 & $93,574,358$ & $112,740,976$ & $19,166,618$ \\
\hline
\end{tabular}

\begin{tabular}{|c|c|c|c|c|}
\hline & $22,000,000.00$ & $21,469,466.23$ & \multirow{4}{*}{$19,166,618.21$} & \multirow{5}{*}{$\begin{array}{l}\text { Pit } 14 \text { (SR 6) } \\
\text { Pit } 14 \text { (SR 7) }\end{array}$} \\
\hline & $21,000,000.00$ & & & \\
\hline $\begin{array}{l}\mathscr{A} \\
\tilde{D}\end{array}$ & $20,000,000.00$ & & & \\
\hline & $19,000,000.00$ & & & \\
\hline & $18,000,000.00$ & Block Sequ & ce Scenario & \\
\hline
\end{tabular}

Figure 10. Profit Comparison Between Pit 14 SR 6 and SR 7

In choosing the best scenario between SR 6 and SR 7, it need to be validated by calculating the possible profit from that scenario. From that, the best possible scenario can be chosen. The profit calculation results can be seen in Table 9.

Based on Figure 10, it shows that the possible profit of Pit 14 SR 6 is $\$ 21,469,466.23$ and Pit 14 SR 7 is $\$ 19,166,618.21$. It can be concluded that Pit 14 SR 6 gives more profit than Pit 14 SR 7. The profit calculation was done by using Mining Operational Costs issued by Directorate General of Coal and Minerals on Kepdirjen Minerba No. 579.K/32/DJB/2015.

\section{Conclusion}

The coal reference price (in Indonesian: HBA) in the initial period was suffered a significant decrease of $\$ 76.57 /$ ton (May 2019) which previously is $\$ 90.57 /$ ton. After a significant decrease, the coal reference price (HBA) predicted to be increase at the maximum value of \$87.31/ton (January 2023).

The optimal stripping ratio were obtained by trial and error and still considering the company's geotechnical recommendation is $\mathrm{SR}=6$ and $\mathrm{SR}=7$. Estimated revenue of Pit 14 (SR 6) for coal production in 2020 at Quarter $1=$
$\$ 40,131,297.12$, Quarter $2=\$ 36,431,457.31$, and Quarter $3=\$ 19,601,965.40$, whereas the estimated revenue of Pit 14 (SR 7) for coal production in 2020 at Quarter $1=$ $\$ 41,821,080.50$, Quarter $2=\$ 39,204,128.39$, and Quarter $3=\$ 31,715,767.60$.

\section{Acknowledgements}

The authors convey special gratitude to PT Alamjaya Bara Pratama for all support to this research.

\section{References}

[1] Engineering and Production Division. 2019. PT Alamjaya Bara Pratama.

[2] Hartman, H.L. 1987. Introductory Mining Engineering. Alabama: John Wiley \& Sons.

[3] Aswandi, D dan Yulhendra, D. 2013. Redesain Rancangan Ultimate Pit dengan Menggunakan Software Minescape 4.118 di Pit S41 PT Energi Batu Hitam Kecamatan Muara Lawa dan Siduq Ngurai Kabupaten Kutai Barat Provinsi Kalimantan Timur. Jurnal Bina Tambang. Vol. 4, No. 1, 153-164.

[4] Ismail, Z., Yahya, A., Shabri, A. 2009. Forecasting Gold Prices Using Multiple Linear Regression Method. American Journal of Applied Sciences, Vol. 6, No. 8.

[5] Supranto, J. 2005. Ekonometri Buku Kedua. Jakarta: Ghalia Indonesia. 